\title{
İșletmelerin Kurumsal Sosyal Sorumluluk Uygulamalarında Kurumsal Yönetim Yapılarının Etkisi: BİST 100 Üzerine Bir Uygulama
}

\author{
Şerife ÖNDER * \\ Erdoğan KAYA**
}

\section{ÖZET}

İşletmelerin toplum ve çevre bilinci ile faaliyetlerini sürdürmesini esas alan kurumsal sosyal sorumluluk uygulamaları, işletmelerin kurumsal yönetim anlayışının bir parçasıdır. Bu çalışmanın amacı Türkiye'de işletmelerin kurumsal sosyal sorumluluk uygulamalarında kurumsal yönetim yapılarının etkisini incelemektir.

Çalışmada 2016 yılı Borsa İstanbul BiST 100 endeksinde işlem gören işletmelere ait veriler kullanılmıştır. Işsletmelerin kurumsal sosyal sorumluluk uygulamalarında kurumsal yönetimin etkisi İkili Lojistik Regresyon tekniği ile analiz edilmiştir. Yapılan analiz sonucunda Türkiye'de işletmelerin kurumsal sosyal sorumluluk uygulamaları ile kurumsal yönetim düzeyleri arasında istatiksel açıdan anlamlı bir ilişki bulunmadiğı tespit edilmiştir. Ayrıca işletme büyüklügü̈, endüstri profili, halka açılılk oranı ve öz sermayenin defter değeri değişkenleri ile işletmelerin kurumsal sosyal sorumluluk uygulamaları arasında istatistiki açıdan anlamlı ve pozitif yönde bir ilişki bulunduğu tespit edilmiştir.

Anahtar Kelimeler: Kurumsal Sosyal Sorumluluk, Kurumsal Yönetim, BIST

JEL Sinıflandırması: M14, M40.

\section{The Effect of Corporate Governance In Corporate Social Responsibility} Implementations Of Businesses: An Application On BIST-100 Companies

\section{ABSTRACT}

Corporate social responsibility which is based on the operating of businesses with an environmental consciousness is considered as a part of their corporate governance philosophy. The aim of this study is to examine the effect of corporate governance in corporate social responsibility implementations.

In this study, data belonging to 91 firms whose shares have been traded within BIST-100 index of Borsa Istanbul in the year of 2016, have been used. The effect of corporate governance in corporate social responsibility implementations has been analyzed by using Binary Logistic Regression Technique. As the main result of the analysis there wasn't any statistically significant relationship determined between Turkish firms' levels of corporate governance and their corporate social responsibility implementations. Moreover; firm size, industry profile, percentage of publicly traded shares and book value of equity capital control variables have statistically significant direct relation with corporate social responsibility implementations of firms.

Keywords: Corporate Social Responsibility, Corporate Governance, BIST

Jel Classification: M14, M40.

\footnotetext{
* Yrd. Doç. Dr. Şerife Önder, Dumlupınar Üniversitesi, Kütahya Sosyal Bilimler Meslek Yüksekokulu.

** Erdoğan Kaya. Dumlupınar Üniversitesi, Sosyal Bilimler Enstitüsü.
} 


\section{GİRIŞ}

Sosyal sorumluluk bütün dünyada kabul görmüş evrensel bir kavramdır. Bu kavramın uygulanabilirliğinin temel kaynağı; doğruluk, tarafsızlık, adalet gibi ahlaki değerlerledir. Sosyal sorumluluk kavramı, kişi ya da işletmelerin topluma karşı olan sorumluluklarını belirtmektedir (Y1lmaz ve Alkan, 2006: 730). Kurumsal sosyal sorumluluk kavramı, kurumsal hayırseverlik, kurumsal vatandaşlık, iş etiği, kurumsal sorumluluk, sosyal sorumluluk yatırımları, sürdürülebilirlik gibi çeşitli terimlerin bileşimi olarak bilinen bir kavramdır (Silberhorn ve Warren, 2007: 353). Fakat bu kavram üzerinde uzlaşılmış ortak bir tanımı söz konusu değildir (Hopkins, 2004: 213). Bundan dolayı kurumsal sosyal sorumlulukla ilgili birden fazla tanımlama yapılmıştır. Genel olarak kurumsal sosyal sorumluluğun en basit tanımı "işletmelerin faaliyetlerini sürdürürken kar elde etmenin ötesinde topluma ve çevreye yönelik belli sorumlulukları olduğu fikri" olarak tanımlanmaktadır (Mescon vd., 2001: 48).

İşletmeler verdikleri karalarda toplumsal ve çevresel olarak ahlaki davranmadıkları takdirde çeşitli yaptırımlarla karşılaşmaktadır. Bu yaptırımlar bazen kamu otoritesi tarafından cezalandırmak olduğu gibi bazen de tüketiciler üzerinde oluşacak negatif algı ile de olabilmektedir. İşletmeler karşılaştıkları bu yaptırımlar nedeniyle kurumsallaşmaya gitmişlerdir. Böylece kurumsal sosyal sorumluluk kavramı ortaya çıkmıştır. İşletmeler 1950'li yıllardan 1960'lı yıllara kadar genellikle topluma karşı odaklanan teoriler ile ilgilenmişken 1960'lı yıllardan sonra işletmenin ekonomik ve teknik ihtiyaçlarının ötesinde bir sosyal sorumluluk anlayışı benimsemişlerdir. Günümüzde ise kurumsal sosyal sorumluluk ekonomik büyümenin ötesinde sosyal ve çevresel faktörlerde de sürdürülebilir olmanın bir anahtarı haline dönüşmüştür (Büyükyılmaz ve Fidan, 2015:365). İşletmeler gerek yasal zorunluluklar sonucunda gerekse de gönüllülük esasında sosyal sorumluluk faaliyetleri gerçekleştirmektedirler. Bu faaliyetleri gerçekleştirirken stratejik amaçlı davranabildikleri gibi tamamen hayırseverlik amacı da güdebilmektedirler. İşletmenin gerçekleştirdiği kurumsal sosyal sorumluluk faaliyetleri her ne sebeple gerçekleştirilirse gerçekleştirilsin bu faaliyetler işletmelere rekabetçi avantaj sağlamaktadır (Demir, 2013:227).

İşletmelerin ekonomik büyüme ve karlılık odaklı yaklaşımlarının, çevresel, ekonomik ve sosyal performans odaklı üçlü sorumluluk (triple bottom line) yaklaşımına evirilmesi kurumsal sürdürülebilirliğin gerçekleştirilebilmesinde önemli bir etken olmuştur. İşletmelerin bu üçlü sorumluluk yaklaşımının kabullenmesi, aynı zamanda, 'kurumsal yönetim' inde gerekliliğini ortaya çıkarmıştır. İşletmenin iç ve dış paydaşlara karşı sorumluluklarını ahlaki ve etik kurallar çerçevesinde düzenleyen kurumsal yönetim ilkeleri aynı zamanda kurumsal sürdürülebilirliğin sağlanmasını ve kurumsal sosyal sorumluluğun çerçevesini belirleyen temel etken olmaktadır (Kavut, 2010:11). Özellikle 1980'li y1llardan sonra ortaya çıkan yeni ekonomik düzen ülkelerin makroekonomik yapılarında önemli değişiklikler yaptığı gibi, işletmeleri de yönetim yapılarında yeni ve aykırı düzenlemeler yapmaya zorlamıştır. Ortaya çıkan yeni yönetim düzeninde işletmelerin varlığını sürdürmesinde yeni kurumsal yönetim teknikleri önem kazanmaya başlamıştır (Kuşat, 2012:237). Günümüzde kurumsal sosyal sorumluluk ve kurumsal yönetim anlayışının birbirini tamamlayıcı bir nitelikte birlikte işlemesi, işletmelerin önem verdiği bir konu haline gelmiştir.

Bu çalışmada Türkiye'de işletmelerin kurumsal sosyal sorumluluk uygulamalarında kurumsal yönetimin etkisini incelemek ve işletmelerin kurumsal sosyal sorumluluk uygulamalarını etkileyen faktörleri tespit etmek amaçlanmaktadır. Bu amacı gerçekleştirmek 
için BIST 100 endeksinde işlem gören işletmelerin 2016 y1lına ait finansal verileri kullanılarak ikili lojistik regresyon analizi gerçekleştirilmiştir.

\section{KURUMSAL YÖNETIM VE KURUMSAL SOSYAL SORUMLULUĞUN TARIHSEL GELIŞİMINE KISA BİR BAKIŞ}

Kurumsal yönetim teriminin kökenini 16. yy. kadar gittiği iddia edilmektedir. "Governance" terimi 18.yy'da, hükümeti sivil toplumla uzlaştırmaya çalışan bir yaklaşımı ifade etmek üzere kullanılmıştır (Gaudin, 1998: 47). Günümüzdeki anlamıyla kurumsal yönetim kavramı ilk olarak 1990'lı yıllarda kullanılmaya başlanmıştır. Özellikle ilgili dönemde yaşanan finansal krizler söz konusu kavramın daha da önemli bir hale gelmesine neden olmuştur (Öztürk ve Demirgüneş, 2008:396).

1990'l1 yıllarda sermaye piyasalarında yaşanan ve tüm dünyayı etkileyen finansal skandallardan sonra kurumsal yönetim ile ilgili evrensel ilkelerin geliştirilmesi ihtiyacı ortaya çıkmıştır. Bu ihtiyacı karşılayabilmek için 1999 yılında OECD "Kurumsal Yönetim İlkeleri" ismiyle uluslararası ölçeği kapsayan ilk rapor yayımlanmıştır. OECD’ye üye ülkeler bu raporu referans alarak kurumsal yönetim ilkelerinin uygulamasına yönelik mevzuat geliştirme çabalarına girişmişlerdir (Kula ve Baykut, 2014:3).

Türkiye'de ise kurumsal yönetimle ilgili ilk çalışma TÜSİAD tarafından yapılmıştır. TÜSİAD Şirket İşleri Komisyonu altında Kurumsal Yönetim Çalışma Gurubunu kurmuş ve bu komisyon yapılan çalışmaların sonucunda 2002'de Kurumsal Yönetimin Uygulama Kodunu hazırlayarak yayınlamıştır. Ayrıca TÜSİAD'ın başkanlığında kurumsal yönetimin özel ve kamu kurumlarında benimsenerek hayata geçirilmesi amaciyla Türkiye Kurumsal Yönetim Derneği (TKYD) 1 Ocak 2003 'de kurulmuştur ( http://www.tkyd.org).

Kurumsal Yönetim ilkelerine bağlı olan işletmelerin sermaye piyasalarında ayrıca endekslenmesine yönelik çeşitli çalışmalar yapılarak bu alanda farkındalık arttırılmaya çalışılmıştır. Tayvan, Japonya, Kore, Filipinler gibi gelişmiş ve gelişmekte olan ülkelerde kurumsal yönetim derecelendirme çalışmaları yapılmış ve bu çalışmalarda Standardand Poors Kurumsal Yönetim Endeksi meydana getirilmiştir (Esendemirli ve Acar, 2016: 626-627).

Kurumsal yönetim endeksleri oluşturulmasına yönelik uluslararası alandaki bu gelişmeler sonucunda Türkiye'de de çalışmalar başlamıştır. Ağustos 2007'de Kurumsal Yönetim Endeksi (XKURY) Borsa İstanbul'da (BİST) hesaplanmaya başlamıştır. Kurumsal Yönetim Endeksinde kurumsal yönetim ilkelerine uyum notu 10 üzerinden en az 7 olan işletmeler yer alabilmektedir. Kurumsal Yönetim İlkelerine uyum notu, SPK tarafindan belirlenmiş derecelendirme kuruluşları tarafından verilmektedir. Derecelendirme işlemi yapılırken işletmenin kurumsal yönetim ilkelerine bir bütün olarak uyumu değerlendirilmektedir. 31.08.2007 tarihinde kurumsal yönetim derecelendirme notu en az 7 olan işletme sayısının 5 olması ile hesaplanmaya başlanan endeks Ağustos 2017 tarihinde 50 işletme ile hesaplanır hale gelmiştir (Kula ve Baykut, 2014:3-4).

Kurumsal yönetim kavramı gibi kurumsal sosyal sorumluluk kavramı da uluslararası alanda yaşanan gelişmelerin 1şığında tüm dünyaya hızla yayılmıştır. Kurumsal sosyal sorumluluk kavramının ilk olarak 17. yy'da İngiltere'de ortaya çıktığı iddia edilmektedir. Söz konusu dönemde İngiliz işletmeleri iktisadi faaliyetlerinin yanında köprü, eğitim kurumları, 
kanal inşaatı yapımı gibi sosyal faaliyetleri de yerine getirmişlerdir. Sanayi devrimi ile karlılıkları artan ve kitlesel üretim yapısına geçen işletmelerin kadın ve çocuk işçi gibi alanlarda daha duyarlı olmasına yönelik baskılar artmaya başlamıştır (Daştan ve Bellikli, 2015:178-179). İkinci Dünya Savaş1 sonrasında ise faaliyette bulunan büyük işletmelerin içinde bulundukları toplumun yapı taşlarına ilişkin sorumluluklarına dikkat çekilmeye başlanmıştır. İlk olarak Sosyal Sorumluluk ile Kurumsal Sosyal Sorumluluk arasındaki farka Howard Bowen 1953'te yayınlanan kitabı ile dikkat çekmiştir (Akkoyunlu ve Kalyoncuoğlu, 2014:128). Howard Bowen'nın 1953 yılında yayınlanan kitabı kurumsal sosyal sorumluluk literatürünün modern zaman başlangıcı olarak kabul edilmektedir. Bowen bu çalışmasında kurumsal sosyal sorumluluğu toplumun değerleri ve öncelikleri açısından arzulanan politikaları izleyerek, gerekli faaliyetleri takip etmek için örgütler tarafından üstlenilmesi gereken yükümlülükler olarak tanımlamaktadır (Demir ve Türkmen, 2015:244).

Kurumsal Sosyal Sorumluluk kavramının üzerinde uzlaşılmış evrensel bir tanımı söz konusu değildir (Verma ve Kumar, 2012:42). Fakat buna rağmen genel olarak tanımlanmak istenirse Kurumsal Sosyal Sorumluluk işletmelerin iç ve diş çevresine karşı sorumlu davranmasını ifade eden bir kavram olarak tanımlanabilir (Demir ve Türkmen, 2015:242).

Kurumsal Sosyal Sorumluluk ve kurumsal yönetim kavramlarının her ikisi de özellikle son 10 yılda Batı dünyasında oldukça gelişmiş ve uygulama alanları artmıştır. Bu kavramlar artık günümüzde işletmelerin uluslararasılaşması ile az gelişmiş ve gelişmekte olan ülkelere de yayılmaya başlamıştır (Verma ve Kumar, 2012:24). Kurumsal sosyal sorumluluğun gelişmesinde önemli olan bir diğer etken olarak Sivil Toplum Kuruluşları (STK) gösterilebilir. STK'lar işletmelerin faaliyetlerini devletin denetim organlarının yaptı̆̆ı gibi sürekli bir şekilde denetlemektedir. Bu denetim faaliyeti gönüllü bir şekilde toplum yararı açısından gerçekleştirilmektedir (Taşlıyan, 2012:23). İşletmelerin Kurumsal Sosyal Sorumluluk faaliyetleri diğer ekonomik faaliyetleri gibi sadece tüketici değil yatırımcı ve diğer dış paydaşları tarafından da izlenmektedir. Bu denetim ve izleme süreçleri özellikle sermaye piyasalarında endeksler aracılı̆̆ ile daha aktif bir şekilde yapılmaktadır.

Kurumsal Yönetim Endeksinde olduğu gibi Kurumsal Sosyal Sorumluluk ile ilgili de sermaye piyasalarında endeksler oluşturulduğu görülmektedir. Dünya'nın pek çok gelişmiş sermaye piyasasında örnekleri bulunmaktadır. Bu endekslere 1999 yilında kurulan Dow Jones Sürdürülebilirlik Endeksi (Dow Jones Sustainability Index - DJSI), Londra Borsası ve Financial Times Gazetesi tarafından 1995 yılında oluşturulmuş olan. FTSE4Good Endeksi, Afrika'nın önde gelen borsası olan Johannesburg Menkul Kıymetler Borsası ve FTSE Russell ile ortaklaşa olan yeni endeks serisi FTSE / JSE Sorumlu Yatırım Endeksi örnek olarak gösterilebilir.

BIST'de dünyada yaşanan bu gelişmelere kayıtsız kalamayarak 4 Kasım 2014 tarihinden itibaren Sürdürülebilirlik Endeksini XUSRD koduyla faaliyete geçirmiştir. XUSRD Endeksine 2014 yılında BIST 30 endeksinde yer alan işletmeler, 2015 y1lında ise BIST 50 endeksinde yer alan işletmeler değerlemeye tabi tutulmuştur. Endeks 2016 yılından itibaren BIST 50 endeksi işletmelerine ek olarak BIST 100 işletmelerinden gönüllü olanları da kapsar hale gelmiştir (www.borsaistanbul.com, 2017). 


\section{LITERATÜR}

Kurumsal sosyal sorumluluk ve kurumsal yönetim ilişkisini inceleyen gerek ulusal gerekse de uluslararası alanda yapılmış teorik çalışmaların yanında ampirik çalışmalarda bulunmaktadır. Bu çalışmalarda panel veri analizinden ikili mülakat yöntemine kadar değişik yöntemler kullanılmaktadır. Bu çalışmalardan öne çıkan bazı çalışmalar aşağıda listelenmektedir.

Haniffa ve Coke (2005), 139 işletmenin yıllık faaliyet raporları üzerinden kendilerinin geliştirmiş olduğu bir kontrol listesine göre ölçtükleri kurumsal sosyal açıklamalar üzerinde kurumsal yönetimin ve kültürün etkisini ölçmüşlerdir. İçerik analizine göre oluşturulan bağımlı değişken kültürün etkisini yönetim ve pay sahiplerinin etnik kökeni üzerinden temsil ederken, kurumsal yönetimi yönetim kurulunun yapısı ile temsil etmektedirler. Malezya'daki işletmeler üzerine 1996 ve 2002 yılları için yapılan bu analiz sonucunda Malay yöneticilerinin baskın olduğu yönetim kurulları ile birden fazla yöneticiliğe sahip yönetim kurulu başkanlarının kurumsal sosyal sorumluluk üzerinde önemli derecede etkili olduğu sonucuna ulaşılmıştır.

Money ve Schepers (2007), FTSE100 işletmelerinden 13'ü üzerinde kurumsal sosyal sorumluluk ve kurumsal yönetim ilişkisini incelemiştir. Yapılan inceleme sonucunda örneklem olarak alınan işletmelerin, kurumsal sosyal sorumluluk uygulamamaları ile kurumsal yönetim yapıları arasında önemli bir uyumun olduğunu ortaya konmuştur. Araştırmacılar bu uyumun nedeninin yaşanan muhasebe skandallarının sonucunda yükselen iş ahlak1 olduğunu ileri sürmektedir.

Jamali vd.(2008) Lübnan'da faaliyet gösteren, aralarında bankalarında bulunduğu sekiz işletmenin üst düzey yöneticileri ile yaptığı derinlemesine görüşme notları ile bu işletmelerdeki kurumsal sosyal sorumluluk ve kurumsal yönetim ilişkisini incelemiştir. Yapılan bu nitel analiz sonucunda araştırmacılar yöneticilerin çoğunluğunun kurumsal yönetimin, kurumsal sosyal sorumluluk için gerekli bir temel şart olarak gördügüunü ileri sürmektedirler.

Kolk’un (2008) Fortune Global 250 listesinde bulunan ve sürdürebilirlik raporu yayınlayan 161 işletmeyi incelediği çalışmasında çok uluslu pek çok işletmenin özellikle Avrupa ve Japonya'da yönetim kurulunun denetim ve sürdürülebilirlik sorumluluklarının yapılandırılmasına başladığına dikkat çekmiştir.

Said ve Haron. (2009), Malezya'da halka açık olan 150 işletmenin 2006 yılında yapmış oldukları kurumsal sosyal sorumluluk ile ilgili açıklamalarını web sitelerinden ve yıllık faaliyet raporlarından toplayarak kurumsal sosyal sorumluluk açıklama endeksi oluşturmuşlardır. $\mathrm{Bu}$ kurumsal sosyal sorumluluk endeksi üzerinde, kurumsal yönetimin unsurları olarak kabul ettikleri yönetim kurulunun büyülüğü, yönetim kurulunun bağımsızlığı, yönetici sahipliği ve sahiplik yapısının etkisini analiz etmişlerdir. Yapılan hiyerarşik regresyon analizi sonucunda denetim komitesinin ve devlet sahipliğinin kurumsal sosyal sorumluluk açıklamaları üzerinde pozitif ve istatistiki açıdan anlamlı bir etkisinin olduğu ortaya konmuştur. 
Kavut (2010), 2003 ve 2004 yıllarında İMKB 100 endeksinde yer alan işletmelerin yıllık faaliyet raporlarını inceleyerek yapmış olduğu frekans dağılımları sonucunda İMKB'de işlem gören işletmeler için kurumsal yönetim ilkelerine uyum yılı olan ilgili dönemde yetersiz olsa da işletmelerin çevreye duyarlı bir kurumsal sosyal sorumluluk anlayışının geliştiğini gözlemlemiştir.

Chann, v.d. (2014), Avustralya Menkul Kiymetler Borsasına kote 222 firmanın finansal raporlarını inceleyerek gerçekleştirmiş oldukları regresyon analizi ile işletmelerin kurumsal sosyal sorumluluk faaliyetleri üzerinde kurumsal yönetim, firma büyüklügü̈, endüstri profili ve kaldıraç derecesi değişkenlerinin pozitif ve istatiksel olarak anlamlı bir ilişki ortaya koyduğunu belirtmişlerdir.

Young ve Tyhil (2014), Avusturalya, Hindistan ve Birleşik Krallıkta faaliyet gösteren 29 işletme üzerinde yarı yapılandırılmış görüşme tekniği kullanarak yaptığı inceleme ile kurumsal yönetim ile kurumsal sosyal sorumluluk arasındaki ilişkinin kurulmasında etkili olan faktörler araştırılmıştır. Araştırmacılar kurumsal sosyal sorumluluk ve kurumsal yönetim arasındaki ilişkinin ekonomik çevre, ulusal yönetişim sistemi, ulusal kültür, hukuki alt yapı ve yatırımcılar tarafından etkilendiği sonucuna ulaşmışlardır.

Poudel (2015) Nepal'de faaliyet gösteren 10 adet bankanın kurumsal sosyal sorumluluk skorları ile kurumsal yönetim skorlarını basit doğrusal regresyon yöntemi ile analiz etmiştir. Yapılan analiz sonucunda kurumsal yönetim skorunun kurumsal sosyal sorumluluk skoru üzerinde önemli derecede pozitif yönde etkili olduğu sonucuna ulaşmıştır.

Daştan ve Belikli (2015), İMKB kurumsal yönetim endeksinde yer alan 48 işletmenin 2009 - 2013 yılları arasındaki verilerini incelemişlerdir. Regresyon ve korelasyon analizi sonucunda işletmelerin kurumsal sosyal sorumluluk göstergelerinin piyasa değeri/defter değeri ile pozitif yönde, özkaynak karlılığı, aktif karlılık ve net kar marjı oranı değerleri ile negatif yönde ilişkili olduğu sonucuna ulaşmışlardır. Ayrıca araştırmacılar kurumsal sosyal sorumluluk uygulamalarına önem veren işletmelerin, hisse senedi getirilerinin bu durumdan pozitif yönde etkilendiği sonucuna ulaşmışlardır.

Habbash (2016), Suudi Arabistan Borsasında 2007-2011 y1lları arasında faaliyet gösteren 267 işletmeyi incelemiştir. İşletmelerin kurumsal sosyal sorumluluk uygulamaları üzerinde karlılık, işletme büyüklüğü, faaliyette bulunulan endüstri, kaldıraç oranı ve işletme yaşı gibi kontrol değişkenleri ile denetim komitesi, yönetim kurulu bağımsızlığı, yönetim kurulu başkanın bağımsızlığı ve sahiplik yapısı gibi kurumsal yönetimi temsil eden değişkenleri kullanarak Regresyon Analizi gerçekleştirmiştir. Yapılan analiz sonucunda işletmelerin kurumsal sosyal sorumluluk uygulamaları üzerinde kurumsal yönetimi temsil eden değişkenlerden sadece sahiplik yapısı istatistiki açıdan anlamlı bir ilişki olduğu ortaya çıkmıştır. Diğer kurumsal yönetimi temsil eden değişkenler istatistiki açıdan anlamsız çıkmıştır.

Okan v.d., (2016) 30 ülkeden seçilen 192 işletmenin yapmış olduğu kurumsal sosyal sorumluluk ile ilgili açıklamaları üzerinde yönetim kurulunun özelliklerinin etkisini ölçmüşlerdir. Yapılan analiz sonucunda yönetim kurulunda bulunan kadın ve doktora yapmış üye sayısı arttıkça yapılan kurumsal sosyal sorumluluk açıklamalarının artacağına ilişkin kanıtlar elde edilmiştir. 
Yapılan çalışmalar göstermektedir ki, Kurumsal Soysal Sorumluluk, işletmelerin faaliyetlerini sürdürürken ürettikleri mal ve hizmetlerin kalitesinin ötesinde, topluma ve çevreye karşı sorumluluklarını yerine getirme biçimidir. Bu sorumluluklar markalaşmanın dışında işletmeye kazandırılan artı değerlerdir. İşletmeler bu değerler ile rekabet avantajı elde ederek faaliyetlerini sürdürmektedirler. Çalışmalar incelendiğinde söz konusu literatürde kurumsal sosyal sorumluluk ve kurumsal yönetim arasındaki ilişkinin İkili Lojistik Regresyon Analizi ile ölçülmediği, daha çok nitel araştırmaların yaygın olarak kullanıldığı görülmektedir. $\mathrm{Bu}$ çalışmada tüm bu sebeplerden dolayı kurumsal sosyal sorumluluk ve kurumsal yönetim arasındaki ilişkiyi literatürde yer alan çalışmalarda kullanılan veriler kullanılarak İkili Lojistik Regresyon Analizi ile inceleyecektir.

\section{ARAŞTIRMANIN AMACI, KAPSAMI, YÖNTEMI VE DEĞİŞKENLERİ}

$\mathrm{Bu}$ çalışma BİST 100 Endeksinde işlem gören işletmelerin kurumsal sosyal sorumluluk faaliyetleri üzerinde kurumsal yönetimin etkisini test etmeyi amaçlamıştır. Bunun için BİST 100'de işlem gören 100 işletme örneklem olarak alınmıştır. Örneklemde yer alan işletmelerin internet sitelerinde ve Kamuyu Aydınlatma Platformunda açıklamış oldukları yıllık finansal raporları kullanılarak işletmelere ilişsin bazı kontrol değişkenleri elde edilmiştir. BİST 100 endeksinde yer alan tüm işletmelere ulaşılmaya çalışılmış ancak analizin yapıldığı tarih itibari ile 2016 yılı faaliyet raporlarını gerek Kamuyu Aydınlatma Platformunda gerekse internet sitelerinde yayınlamayan 9 işletme örneklemden çıkarılmıştır. Sonuç olarak modelde kullanılan verilerin elde edilebildiği işletme sayısı 91 olarak gerçekleşmiştir.

Çalışmada işletmelerin kurumsal sosyal sorumluluk uygulamaları BİST Sürdürülebilirlik Endeksinde yer alması ile ölçülmüştür. $\mathrm{Bu}$ nedenle araştırmanın analiz yöntemi olarak İkili Lojistik Regresyon Analizi seçilmiştir. Sürdürülebilirlik endeksinde 2016 y1lı için toplam 42 işletme yer almaktadır. Yine işletmelerin kurumsal yönetim uygulamaları da Borsa İstanbul Kurumsal Yönetim Endeksinde yer alması ile ölçülmüştür. Kurumsal yönetim endeksinde 2016 yılı için toplam 50 işletme yer almaktadır. Söz konusu işletmelerin tamamı BİST 100 endeksinde yer almaktadır.

İşletmelerde kurumsal sosyal sorumluluk uygulamalarını belirleyen çok farklı değişkenler yer almakla birlikte literatürde en sık kullanılan ve en temel değişken kurumsal yönetim değişkenidir. Bu çalışmada Chann vd. (2014) yapmış olduğu çalışma temel olarak alınmıştır. Söz konusu çalışmada kullanılan model Türkiye için yeniden gözden geçirilerek Eşitlik 1'deki gibi belirlenmiştir. Eşitlik 1'de yer alan modelde Kurumsal Sosyal Sorumluluk (DISC) ve Kurumsal yönetim değiş̧kenlerinin yanında kontrol değişkeni olarak; işletme büyüklüğü (SIZE), endüstri profili (IND), halka açıklık oranı (SHP), öz sermayenin defter değeri (CP) ve ekonomik performans (EP) değişkenleri de kullanılmıştır.

$$
D I S C_{k}=\beta_{0}+\beta_{1} C G_{k}+\beta_{2} S I Z E_{k}+\beta_{3} I N D_{k}+\beta_{4} S H P_{k}+\beta_{5} C P_{k}+\beta_{6} E P_{k}+\varepsilon_{i t}
$$


DISC değişkeni BİST100'de yer alan işletmelerin sürdürebilirlik endeksinde yer alıp almadığ1 ile ölçülecektir. Sürdürülebilirlik endeksinde yer alan işletmeler için 1, yer almayanlar için 0 değeri kullanılacaktır.

CG değişkeni BİST100'de yer alan işletmelerin kurumsal yönetim endeksinde yer alıp almadığ1 ile ölçülecektir. Kurumsal yönetim endeksinde yer alan işletmeler için 1, yer almayanlar için 0 , değeri kullanılacaktır.

SIZE değişkeni işletme büyüklüğünü temsil etmektedir. İşletme büyüklüğü değişkeni işletmelerin toplam varlıklarının (Aktif) TL cinsinden tutarı ile hesaplanacaktır. Bu değişken modelde doğal logoritmass ${ }^{1}$ alınarak kullanılmıştır.

IND değişkeni işletmelerin sektörlere göre dağılımını esas alınarak hesaplanacaktır. $\mathrm{Bu}$ değişken aşağıda belirtilen sektörlerine göre 1-2-3 olarak hesaplanacaktır.

Low (1):Finans sektörü, banka, sigorta işletmesi, gayrimenkul yatırım ortaklığı vb. işletmelerdir.

High (3):Kimya, inşaat malzemeleri, ambalajlama ve paket, madencilik, kâğıt vb. işletmelerdir.

Medium (2):Enerji, sağlık, iletişim vb... 1 ve 3 dışındaki tüm işletmeler için kullanılmıştır.

SHP değişkeni işletmelerin sahiplik yapısını temsil etmektedir. Sahiplik yapısı ise, işletmenin halka açıklık oranı olarak hesaplanmıştır.

CP değişkeni özsermayenin defter değerini temsil etmektedir ve toplam varlıklardan toplam özsermayenin çıkartılmasıyla hesaplanmıştır.

EP değişkeni öz sermaye karlılığını (ROE) göstermektedir. Bu değişken işletmelerin Net kar/Öz sermayeleri ile hesaplanmıştır.

Eşitlik 1'deki modelde yer alan değişkenlerden SIZE, IND, SHP, CP ve EP değişkenlerinin hesaplanmasında Chann vd. (2014)'ın çalışmasında kullanılan yöntem esas alınmıştır. DISC ve CG değişkenleri söz konusu modelde endeks notu olarak kullanılmaktadır. Fakat bu değişkenlerin endeks notu olarak kullanılması durumunda örneklem büyüklüğünden ödün vermek zorunda kalınacağ 1 için bu çalışmada ilgili değişkenler vekil (proxy) değişken olarak kullanılmıştır.

\section{BULGULAR}

Eşitlik 1'de gösterilen ve kurumsal sosyal sorumluluk üzerinde kurumsal yönetimin etkisini ölçmek için kurulan modelde yer alan tüm değişkenlere ilişkin tanımlayıcı istatistikler Tablo1'de gösterilmektedir.

\footnotetext{
${ }^{1}$ Değişkenler arasında dağılım marjını normalize etmek için doğal logaritma alınarak kullanılmıştır.
} 
Tablo 1. Modele İlişkin Tanımlayıcı İstatistikler

\begin{tabular}{llcccc}
\hline Değişkenler & $\mathbf{N}$ & En Düşük & En Yüksek & Ortalama & Standart Sapma \\
\hline DISC & 91 & 0 & 1 & 0,64 & 0,483 \\
IND & 91 & 1 & 3 & 2,10 & 0,870 \\
SHP & 91 & 0,001 & 71,10 & 29,663 & 15,837 \\
SIZE & 91 & 19,494 & 26,465 & 22,227 & 1,779 \\
EP & 91 & $-2,363$ & 449,057 & 6,223 & 47,086 \\
CP & 91 & 0,001 & 24,525 & 20,170 & 4,593 \\
CG & 91 & 0 & 1 & 0,32 & 0,469 \\
\hline
\end{tabular}

Bu değişkenlerden DISC değişkeni ile CG değişkeni 0 ila 1, IND değişkeni ise 1 ila 3 arasında değer almaktadır. SHP değişkeni ise 0,001 ila 71,10 arasında değer alırken ortalama olarak 29,663 değerine ulaşmaktadır. SIZE ve CP değerleri ise logaritmik değerlerdir. CP değişkeni ise -2,363 ila 449,057 arasında değerler almaktadır.

Tablo 2. Hosmer ve Lemeshow Testi

\begin{tabular}{ccc}
\hline Ki-Kare & Serbestlik Derecesi & Önem Düzeyi \\
\hline 7,531 & 8 & 0,481 \\
\hline
\end{tabular}

Eşitlik 1'de gösterilen modelin İkili Lojistik Regresyon Analizine geçmeden, modele ilişkin istikrar ve uyum koşulları araştırılmıştır. Eşitlik 1'deki modelin uyum iyiliğini test etmek için Hosmer ve Lemeshow Testi kullanılmıştır. Hosmer ve Lemeshow Test istatistiğinde Ki-Kare tablo değeri serbestlik derecesine göre incelenmelidir. Tablo 2'de yer alan sonuçlara göre Hosmer ve Lemeshow Ki-Kare değeri 7,531'dir. Hosmer Lemeshow test istatistiği anlamlı çıkmamıştır. Dolayısı ile modelin verilere yeterli ve sağlıklı bir şekilde uymadığına ilişkin hipotezin red edilmesi anlamına gelmektedir. Dolayısı ile söz konusu sonuç, modelin verilere yeterli ve sağlıklı bir şekilde uyduğunu göstermektedir.

Tablo 3. Model Katsayılarına İlişkin Omnibus Testi

\begin{tabular}{|c|c|c|c|c|}
\hline Adım & & Ki-Kare & Serbestlik Derecesi & Önem Düzeyi \\
\hline \multirow{3}{*}{1} & Adım & 37,382 & 6 & 0,001 \\
\hline & Blok & 37,382 & 6 & 0,001 \\
\hline & Model & 37,382 & 6 & 0,001 \\
\hline
\end{tabular}

Lojistik Regresyon Analizinde modelin uygunluğunu belirleyen bir diğer test Omnibus Testidir. $\mathrm{Bu}$ test sadece sabitin yer aldığı model ile bağımsız değişkenlerin dahil olduğu model arasında fark olup olmadığını test etmektedir. Tablo 3'te Omnibüs Testi Ki-Kare değeri 37,382 olduğu ve serbestlik derecesi 6 için istatistiki önem düzeyinin 0,001 olduğu görülmektedir. Bu sonuç sadece sabitin yer aldığı model ile bağımsız değişkenlerin yer aldığ model arasında fark olmadığına yönelik hipotezin ret edileceğini göstermektedir. Diğer bir ifade ile bağımlı değişken ile modelde yer alan bağımsız değişkenlerin arasındaki ilişkinin varlığını göstermektedir. 
Tablo 4.Sinıflandirma Tablosu

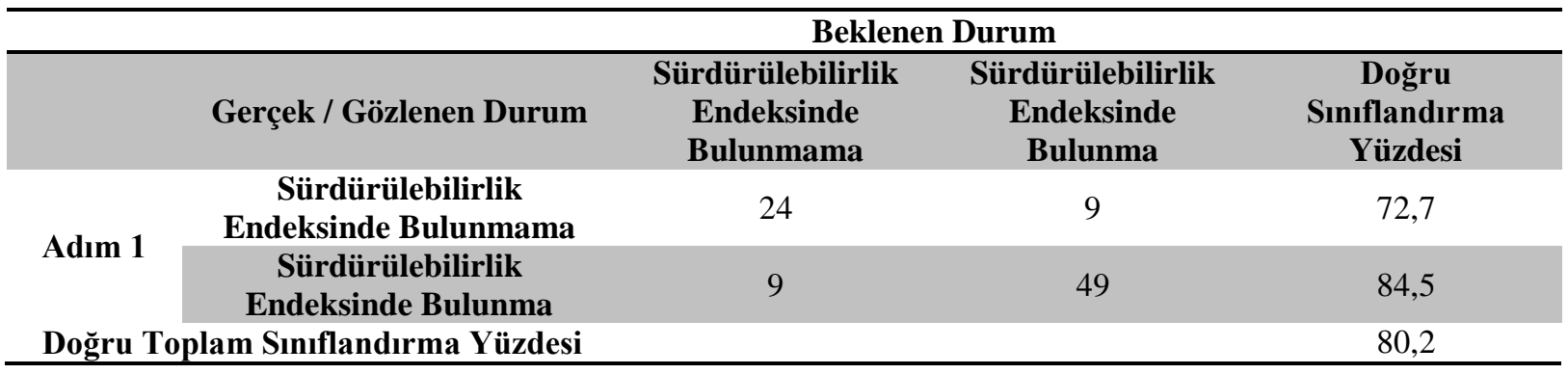

İkili Lojistik Regresyon Analizinde iki kategoriden oluşan bağımlı değişkeni açıklamak için tahmin edilen regresyon modelinde oluşturulan kategorilerin, gerçek duruma ne kadar iyi uyduğu sınıflandırma tablosu ile gösterilmektedir. Dolayısı ile sınıflandırma tablosu da modelin genel olarak uyumunu göstermektedir. Tablo 4'te Sürdürülebilirlik Endeksinde yer almayan 33 işletmeden 24'nün doğru olarak sinıflandırıldığ sınıflandırma yüzdesinin \%72,7 olduğu görülmektedir. Diğer taraftan Sürdürülebilirlik Endeksinde yer alan 58 işletmenin ise 49 tanesi doğru sinıflandırılarak doğru sinıflandırma yüzdesinin \%84,5 olarak gerçekleştiği görülmektedir. Toplam sınıflandırma yüzdesi ise \%80,2 olarak gerçekleşerek model veri uyumunun önemli derecede iyi olduğu görülmektedir.

Tablo 5. Modelin Özeti

\begin{tabular}{cccc}
\hline \multirow{2}{*}{ Adım 1} & -2 LogLikelihood & Cox\&Snell R Kare & Nagelkerke R Kare \\
\cline { 2 - 4 } & 81,814 & 0,337 & 0,461 \\
\hline
\end{tabular}

Cox\&Snell $\mathrm{R}^{2}$ ve Nagelkerke $\mathrm{R}^{2}$ değerleri Çoklu Regresyon Modellerinin analizindeki $\mathrm{R}^{2}$ değerlerine benzemektedir. Bu iki $\mathrm{R}^{2}$ değeri bağımlı değişkende meydana gelen bir değişimin bağımsız değişkenler tarafindan açıklanma derecesini göstermektedir. $\mathrm{Bu}$ değerler 1'e yaklaştıkça modelin mükemmele ulaştığını ifade etmektedir. $\mathrm{Bu}$ iki $\mathrm{R}^{2}$ değerlerinden Cox\&Snell $\mathrm{R}^{2 \text { ' } n i n ~ 1 ' e ~ u l a s ̧ m a s ı ~ o l d u k c ̧ a ~ g u ̈ c ̧ t u ̈ r . ~ N a g e l k e r k e ~} \mathrm{R}^{2}$ değeri Cox\&Snell $\mathrm{R}^{2}$ değerinin değişime uğratılarak 0 ila 1 ranjı arasına indirgenmiş halidir. Dolayısı ile Nagelkerke $\mathrm{R}^{2}$ değeri Cox\&Snell $\mathrm{R}^{2}$ değerinden her zaman büyük olacağ söylenebilir. Tablo 5'teki $\mathrm{R}^{2}$ değerleri incelendiğinde işletmelerin sürdürülebilirlik endeksinde yer alıp almamasına yönelik analiz edilen modelin bağımlı değişkeninde meydana gelen varyansın, Cox\&Snell $\mathrm{R}^{2}$ 'ne göre 0,34 'lük, Nagelkerke $\mathrm{R}^{2}$ değerine göre ise 0,46 'lık kısmı modelde yer alan bağımsız değişkenler tarafından açıklanmaktadır. $\mathrm{Bu}$ oran iyi sayılabilecek bir oran olarak kabul edilebilir ${ }^{2}$. Tablo5'te yer alan -2 LogLikelihood değeri adım adım model geliştirmek için kullanılan olabilirlik değeridir. Dolayısı ile burada yapılan analizde yorumlanmasina gerek yoktur.

\footnotetext{
${ }^{2}$ Haller J. (2013:158), Nagelkerke R2 değeri için 0,2'den büyük değerleri “kabul edilebilir”, 0,4'den büyük değerleri "iyi”, 0,5 'den büyük değerleri ise "çok iyi” olarak tanımlamaktadır.
} 
Tablo 6. Modelin Analizi Sonucunda Değişkenlerin Katsayıları

\begin{tabular}{|c|c|c|c|c|c|c|c|c|}
\hline & \multirow{2}{*}{ B } & \multirow{2}{*}{$\begin{array}{l}\text { Standart } \\
\text { Hata }\end{array}$} & \multirow{2}{*}{ Wald } & \multirow{2}{*}{$\begin{array}{l}\text { Serbestlik } \\
\text { Derecesi }\end{array}$} & \multirow{2}{*}{$\begin{array}{l}\text { Önem } \\
\text { Düzeyi }\end{array}$} & \multirow{2}{*}{$\operatorname{Exp}(B)$} & \multicolumn{2}{|c|}{$\begin{array}{l}\text { 95,0\% C.I.for } \\
\text { EXP(B) }\end{array}$} \\
\hline & & & & & & & $\begin{array}{l}\text { Alt } \\
\text { Sinır }\end{array}$ & $\begin{array}{l}\text { Üst } \\
\text { Sinır }\end{array}$ \\
\hline IND & 0,853 & 0,354 & 5,796 & 1 & $0,016^{* *}$ & 2,346 & 1,172 & 4,697 \\
\hline SHP & 0,036 & 0,021 & 2,939 & 1 & $0,086 * * *$ & 1,037 & 0,995 & 1,080 \\
\hline EP & 0,093 & 0,076 & 1,493 & 1 & 0,222 & 1,097 & 0,945 & 1,274 \\
\hline CG & $-0,045$ & 0,745 & 0,004 & 1 & 0,952 & 0,956 & 0,222 & 4,115 \\
\hline CP & 0,127 & 0,066 & 3,743 & 1 & $0,053^{* * *}$ & 1,135 & 0,998 & 1,291 \\
\hline SIZE & 1,136 & 0,298 & 14,57 & 1 & $0,001^{*}$ & 3,114 & 1,738 & 5,579 \\
\hline Sabit & $-29,72$ & 7,386 & 16,197 & 1 & $0,001^{*}$ & 0,001 & & \\
\hline
\end{tabular}

Sürdürülebilirlik endeksinde yer alıp almamaya göre oluşturulan İkili Lojistik Regresyon Modelinin analizinde modelin geneline ilişkin uyum istatistikleri incelenip, genel olarak modelin anlamlı ve uyumunun iyi olduğu sonucuna ulaşıldıktan sonra, artık modelde yer alan bağımsız değişkenlerin katsayılarının analizine sıra gelmiştir. Tablo 6'da modelde yer alan 6 bağımsız değişkenin işletmelerin sürdürülebilirlik endeksinde yer alma olasılığına ilişkin katsayıları ve istatistiki açıdan önem düzeyleri gösterilmektedir. Tabloda yer alan Wald değerleri Çoklu Doğrusal Regresyondaki t değerine benzemektedir. Katsayıların anlamlılığını değerlendirmede kullanılmaktadır. Fakat burada katsayıların istatistiki açıdan anlamlılı̆ı Önem Düzeyi sütununda yer alan değerlere göre yapılacaktır. Buna göre EP ve CG değişkenleri istatistiki açıdan \%10 önem düzeyinde anlamsız bulunmuştur. Diğer değişkenlerden SIZE değişkeni \%1, IND değişkeni \%5, SHP değişkeni ile CP değiş̧kenleri \%10 önem düzeyinde istatistiki açıdan anlamlı bulunmuşlardır. Değiş̧enlerin istatistiki açıdan anlamlılı̆ııın değerlendirilmesinden sonra sıra katsayılarına gelmiştir.

Katsayıların değerinin yorumlanmasında "B" orijinal beta katsayısından ziyade $\operatorname{Exp(B)~katsayısını~kullanmak~daha~doğrudur.~} \operatorname{Exp}(\mathrm{B})$ katsayıları yorumlanırken katsayı değerinden 1 çıkararak kalan değerin yorumlanması gerekmektedir. Çünkü $\operatorname{Exp}(\mathrm{B})$ katsayıları " $\mathrm{B}$ " orijinal beta katsayılarının logaritmik dönüşüme tabi tutulmuş değerlerdir. $\operatorname{Exp}(\mathrm{B})$ katsayısı 1 olması "B" orijinal beta katsayının sıfır olması anlamına gelmektedir. Buna göre istatistiki açıdan anlamlı çıkan değişkenlerden IND değişkeninde meydana gelen 1 birimlik artış yönünde değişim, işletmeleri sürdürülebilirlik endeksinde bulunma ihtimalini $[(2,346-$ 1)*100] \%134,6 arttırmaktadır. SHP değişkeninde meydana gelen 1 birimlik artış yönünde değişim, işletmelerin sürdürülebilirlik endeksinde bulunma ihtimalini [(1,037-1)*100] \%3,7 arttırmaktadır. Diğer bir istatistiki açıdan anlamlı çıkan CP değişkeninde meydana gelen 1 birimlik artış, işletmelerin sürdürülebilirlik endeksinde bulunma ihtimalini [(1,135-1)*100] $\% 13,5$ arttırmaktadır. Son olarak SIZE değişkeninde meydana gelen 1 birimlik artı̧s yönünde değişim, işletmelerin sürdürülebilirlik endeksinde bulunma ihtimalini [(3,114-1)*100] \%211,4 arttırmaktadır.

\section{SONUÇ}

Sanayi devrimi sonrasında işletmelerin büyümeye başlaması ve içinde bulundukları toplumun ihtiyaçlarına cevap vermeye çalışması sonucunda, modern anlamda gelişen kurumsal sosyal sorumluluk anlayışı, küreselleşme ve çok uluslu işletmeler eliyle tüm dünyaya yayılmaya başlamıştır. Kurumsal sosyal sorumluluk anlayışının işletmelerde 
gelişimini açıklayan çok sayıda teori olduğu gibi pek çok ampirik çalışmada bulunmaktadır. $\mathrm{Bu}$ çalışmalar kurumsal sosyal sorumluluk anlayışının gelişmesinde etkili olan hem işletme dışı hem de işletme içi faktörleri tespit etmeye çalışmaktadır. Böylece işletmeleri kurumsal sosyal sorumluluk uygulamalarında gelişmeye zorlayan temel dinamikler açıklanmak istenmektedir. Bu alandaki literatürde özellikle işletmelerin finansal performansları kadar, işletmenin sahip olduğu kurumsal yönetim anlayışı da önemli bir yer tutmaktadır.

$\mathrm{Bu}$ çalışmada işletmelerin kurumsal sosyal sorumluluk uygulamalarında kurumsal yönetim yapılarının etkisi incelenmiştir. İşletmelerin kurumsal sosyal sorumluluk uygulamaları, kurumsal yönetim ilişkisi ve kontrol değişkenleri (işletme büyüklügüu, endüstri profili, halka açıklık oranı, öz sermayenin defter değeri ve ekonomik performans) ile açıklanmaya çalışılmıştır. Bu yüzden BİST 100 endeksinde yer alan 91 işletmeye ait 2016 yılına ait verileri incelenmiş ve işletmelerin kurumsal sosyal sorumluluk uygulamalarında kurumsal yönetim yapılarının etkisi belirlenmiştir. Gerçekleştirilen İkili Lojistik Regresyon Analizinin sonuçlarına göre Türkiye'de kurumsal sosyal sorumluluk uygulamaları ile işletme büyüklüğü arasında pozitif bir ilişki bulunduğu tespit edilmiştir. Bunun nedeni, Türkiye'de işletme büyüklüğ̈̈ arttıkça, toplumsal ve çevresel baskıların artması olabilir. Nasıl ki toplumda zengin olan bireylerin olmayanlara göre daha fazla hayırsever davranmaları beklenmekteyse, aynı şekilde büyük işletmelerinde daha küçük işletmelere göre daha fazla sosyal sorumluluk uygulamalarında bulunması beklenmektedir. Diğer taraftan işletme büyüklüğü yüksek olan işletmeler faaliyette bulundukları sektörlerde genellikle tekelci bir güce sahiptirler. Bu tekelci güç kamuoyu nezdinde kötü bir imaj oluşmasına neden olabilir. $\mathrm{Bu}$ işletmeler kurumsal sosyal sorumluluk uygulamaları ile bu imajı da düzeltmeye yani kurumsal itibarı yükseltmeye çalışmaktadır.

İşletmelerin kurumsal sosyal sorumluluk uygulamaları ile endüstri profili arasında da istatistiki açıdan anlamlı ve pozitif ilişki bulunmuştur. Ortaya konan ilişki modelde yer alan diğer değişskenlere göre en yüksek düzeydedir. Diğer bir ifade ile işletmelerin kurumsal sosyal sorumluluk uygulamalarını en çok etkileyen unsur, işletmelerin bulunmuş olduğu endüstridir. Yüksek profilli işletmelerin orta profilli işletmelere göre daha fazla kurumsal sosyal sorumluluk uygulamalarında bulundukları tespit edilmiştir. Hatırlanacağı üzere yüksek profilli olan işletmeler Kimya, İnşaat, Madencilik Kağıt ve Ambalaj vb. sektörlerde faaliyet gösteren işletmeleri tanımlamaktadır. Bu işletmelerin toplumsal ve çevresel olarak verdikleri negatif etkiler diğerlerine göre daha yüksektir. Bu etkilerin toplum nezdinde ortaya çıkardı $\breve{g}$ itibar kaybı, kurumsal sosyal sorumluluk uygulamaları ile giderilmek istendiği anlaşılmaktadır.

Analiz sonuçlarına göre Türkiye'de işletmelerin kurumsal sosyal sorumluluk uygulamalarını etkileyen bir başka değişken de halka açıklık oranıdır. İşletmelerde halka açıklık oranı arttıkça, kurumsal sosyal sorumluluk uygulamaları da artmaktadır. Bunun nedeni halka açıklık oranı arttığında mevcut hissedarların yöneticiler üzerinde sosyal sorumluluk üzerine baskılarının artması olabilir. Ayrıca işletmelerde özellikle potansiyel hissedarların ilgisini ve dikkatini çekmek içinde kurumsal sosyal sorumluluk uygulamalarına ilgi artışı sağlanmış olabilir.

İşletmelerin kurumsal sosyal sorumluluk uygulamaları ile öz sermayenin defter değeri arasında da istatistiki açıdan anlamlı ve pozitif ilişki bulunmuştur. Bu değişken birçok çalışmada kaldıraç oranı veya alacaklı gücü gibi kavramlarla da ifade edilmektedir. 
Türkiye'de işletmelerin öz sermayenin defter değeri oranı artıkça kurumsal sosyal sorumluluk uygulamalarının da arttığı tespit edilmiştir. İşletmelerin kurumsal sosyal sorumluluk faaliyetlerini yükselterek potansiyel kredi verenlerin dikkatini çekmeyi amaçladiğı bu sonuç üzerinden ileri sürülebilir.

Son olarak işletmelerin ekonomik performansı da kurumsal sosyal sorumluluk uygulamalarını etkilediği düşünülen bir diğer değişkendir. Analiz sonuçlarına göre Türkiye'de işletmelerin ekonomik performansı ile kurumsal sosyal sorumluluk uygulamaları arasında istatistiki açıdan anlamlı bir ilişki bulunmamıştır. Genel olarak ekonomik performansın işletmenin kurumsal sosyal sorumluluk uygulamalarına olumlu etki yapması beklense de, belki de kurumsal sosyal sorumluluk işletme performansını etkilemektedir. Bu sorunun cevabı daha sonra yapılacak çalışmalar ile ortaya konulabilir.

Yapılan analiz sonucunda anlamlı bir ilişki ortaya çıkmayan bir diğer değişken araştırmanın öznesi konumunda bulunan Kurumsal Yönetim değişkenidir. Türkiye’de işletmelerin kurumsal sosyal sorumluluk uygulamaları ile kurumsal yönetim yapısı arasında anlamlı bir ilişki bulunmadığı tespit edilmiştir. Benzer bir sonuç Habbash (2016) çalışmasında da ortaya çıkmıştır. Türkiye'de işletmelerin kurumsal sosyal sorumluluk uygulamaları ile kurumsal yönetim yapısı arasında anlamlı bir ilişkinin bulunmamasının nedeni; Türkiye'nin gelişmekte olan ülkeler arasında olması, işletmelerde kurumsal yönetim uygulamalarının tam oturmamış olması, kurumsal sosyal sorumluluk uygulamalarının işletmeler için çok yeni bir uygulama olması olabilir.

Türkiye'de de kurumsal yönetim ile ilgili hem gönüllü hem de yasal birçok çalışma yapılmış olmasına rağmen, işletmelerde güçlü bir kurumsal yönetim yapısının olmayışının yanında. Kurumsal Yönetim Endeksinde yer alan işletmelerin sayısının azlığı da bu söz konusu sonucun ortaya çıkmasına neden olmuş olabilir. Bu sebeple ilk olarak Türkiye'de işletmelerin kurumsal yönetim yapılarının güçlendirilmesini sağlayacak yasal düzenlemelerin yapılması gerekmektedir.

\section{KAYNAKLAR}

Akkoyunlu, Gonca Şükriye - Kalyoncuoğlu, Selma (2014), "İşletmelerin Kurumsal Sosyal Sorumluluk Çalışmalarının Marka Algısı Üzerine Etkisinin Değerlendirilmesi”, Niğde Üniversitesi İktisadi ve İdari Bilimler Fakültesi Dergisi, 7 (3):125-144.

Chann, M. C., - Watson J. - Woodliff D. (2014), “Corporate Governance Quality and CSR Disclosures”, Journal of Business Ethics, 125(1): 59-73

Daştan, Abdulkerim - Bellikli Uğur (2015), "Kurumsal Sosyal Sorumluluk ve Muhasebe Etkileşimi: Türkiye'de Kurumsal Yönetim Endeksine Dâhil İşletmelerde Bir Araştırma”, Eskişehir Osmangazi Üniversitesi İİBF Dergisi, 10(1), 177- 208.

Demir, Berna (2013), "Kurumsal Sosyal Sorumluluk ve Muhasebe, Eğitim ve Öğretim Araştırmaları Dergisi”, 2(3): 225-233. 
Demir, Rıza - Türkmen, Erman (2015), "Çalışanların Kurumsal Sosyal Sorumluluk Algılarının Demografik Değişkenler Açısından İncelenmesi”, Yönetim ve Ekonomi Araştırmaları Dergisi, 13(3):242-263.

Gaudin, J. (1998), “Modern Governance, Yesterday and Today: Some Clasifications to be Gained from French Government Policies”. International Social Science Journal, 50(155), 47-56.

Habbash, Mury, (2016), "Corporate Governance and Corporate Social Responsibility Disclosure: Evidence From Saudi Arabia”, Journal of Economic and Social Development, 3(1):87-103.

Haller, Jörg, (2013), Open Evaluation Integrating Users into the Selection of New Product Ideas, Springer Publishing, Nürnberg, Almanya.

Haniffa, R.M., - Cooke, T.E. (2005), “The Impact of Culture and Governance on Corporate Social Reporting”, Journal of Accounting and Public Policy, 24 (5): 391-430.

Jamali, D. - Safieddine A. M. - Rabbath, M. (2008), "Corporate Governance and Corporate Social Responsibility Synergies and Interrelationships”, Corporate Governance: An International Review, 16(5):443-459.

Kavut, Lerzan (2010), “Kurumsal Yönetim, Kurumsal Sosyal Sorumluluk Ve Çevresel Raporlama: İMKB 100 Şirketlerinin Çevresel Açıklamalarının İncelenmesi”, İstanbul Üniversitesi İşletme İktisadı Enstitüsü Yönetim Dergisi, 66:9-43.

Kolk, Ans (2008), "Sustainability, Accountability and Corporate Governance: ExploringMultinationals' Reporting Practices” Business Strategy and the Environment, 18, 1-15.

Kula, Veysel - Baykut, Ender (2014), “Kurumsal Yönetim Derecelendirme Notu ile Piyasa Değeri Arasındaki İlişki: BIST XKURY Şirketleri Üzerine Bir Araştırma”, Uşak Üniversitesi Sosyal Bilimler Dergisi, 7(3):1-17.

Kuşat, Nurdan (2012), "Sürdürülebilir İşletmeler İçin Kurumsal Sürdürülebilirlik Ve İçsel Unsurları”, Afyon Kocatepe Üniversitesi, İİBF Dergisi 14(2):227-242.

Money, K. - Schepers, H. (2007), “Are CSR And Corporate Governance Converging? A View From Boardroom Directors and Company Secretaries in FTSE100 Companies in UK”, Journal of General Management, 33 (2): 1-11.

Okan, Tarhan - Koparan, Emrah - Nas, Tülay İlhan (2016), "Yönetim Kurulu Çeşitliliği Ve Kurumsal Sosyal Sorumluluk Söylemleri Arasındaki İlişki: Kurumsal Çevrenin Moderatör Etkisi”, Ankara Üniversitesi SBF Dergisi, Cilt 7 (2): 465-516.

Öztürk, Mutlu, Başaran - Demirgüneş, Kartal (2008), Kurumsal Yönetim Bakış Açısıyla Entellektüel Sermaye, Selçuk Üniversitesi Sosyal Bilimler Enstitüsü Dergisi, 19(1):395-411. 
Poudel, R. L. (2015), "Relationship Between Corporate Governance and Corporate Social Responsibility: Evidence From Nepalese Commercial Banks”, The Journal of Nepalese Bussiness Studies, 9(1):137-144.

Said, R. Zainuddin - Y., Haron, H, (2009), “The Relationship Between Corporate Social Responsibility Disclosure And Corporate Governance Characteristics in Malaysian Public Listed Companies”, Social Responsibility Journal, 5 (2): 212-226.

Taşlıyan, Mustafa (2012), "Kurumsal Sosyal Sorumluluk Modern İş Dünyasının Vicdanı Gereği”, Ankara Ticaret Odası Yayınları, Ankara.

Verma, D.P. - Kumar, Raj (2012), “Relationship Between Corporate Social Responsibility and Corporate Governance”, OSR Journal of Business and Management (IOSRJBM), 2(3):24-26.

Young, S. - Thyil, V. (2014), “Corporate Social Responsibility and Corporate Governance: Role of Context in International Settings”, Journal of Business Ethics, 122(1):1-24. 
